\title{
Sustainable Technology in Marine Fisheries in Cilacap Regency, Central Java, Indonesia
}

Tri Tiyaningsih*, Suyitno, Kundharu Saddhono

Sebelas Maret University, Surakarta 57126, Central Java, Indonesia

Corresponding Author Email: tiyaningsihtri@student.uns.ac.id

https://doi.org/10.18280/ijdne.150313

Received: 12 March 2020

Accepted: 25 May 2020

\section{Keywords:}

sustainable technology, marine fisheries, fishing gear, production, fishermen, ships, Cilacap Ocean Port

\begin{abstract}
This research aims to describe sustainable technology in marine fisheries in Cilacap Regency, which consists of type of capture equipment, type of fish, type of production and processed products, number of fishermen, and number of vessels. One of the marine fishery support facilities in Cilacap Regency is Cilacap sea fishing port. This port is one of the fishing ports located on the south coast of Java. In order to improve marine products, some efforts are made regarding ship machining, fishing equipment, and fishing aids. In the field of fishing equipment in the development of many environmentally friendly modifications. This method of study is a qualitative descriptive of case study. The data sources used are informants and documents. The results showed with the ongoing technology that 1) there are seven types of sea capture equipment, 2) There are five types of production processing and processed fishery products, 3) There are 5,626 fishermen, and 4) there are 646 vessels based on the size of the vessel and the capture equipment.
\end{abstract}

\section{INTRODUCTION}

Indonesia is one of the countries that has a diversity in the lives of its people. Diversity is divided into several types, namely region and environment, ethnic and cultural, religion, race, group, and gender. The territory of Indonesia from Sabang to Merauke. Indonesia is one of the largest archipelagic countries in the world with so many islands of approximately 17,504 . Where the number of islands that have been standardized and registered by the United Nations is 16,056 islands. The area of inland sea waters and the waters of the Indonesian archipelago is $3,110,000 \mathrm{~km}^{2}$, the area of Indonesia's territorial sea is $290,000 \mathrm{~km}^{2}$, the area of Indonesia's additional zone is $270,000 \mathrm{~km}^{2}$, the area of Indonesia's exclusive economic zone is $3,000,000 \mathrm{~km}^{2}$, the Indonesian continental shelf is $2,800,000 \mathrm{~km}^{2} 108,000 \mathrm{~km}$. Geographically, Indonesia is an archipelagic country, where two-thirds of its territory is marine waters consisting of coastal sea, open sea, bay, and strait [1]. Indonesia is a country that has a large sea area so it has a large potential of fish resources [2]. Marine ecosystems provide various benefits to the community such as the provision of seafood, habitat, offshore space, etc. [3].

The fundamental characteristic that distinguishes the other tribes is the local language, customs, kinship system, regional arts, and the place of origin. Language has been rooted in human life because it has the dominant function in communication [4]. Language is used in interacting with others so that it acts as a communication tool. The main function of the language is as a means of communication [5]. Each country has its own language. The Indonesian state has the Indonesian language which became the national language of the nation, where its function is as a symbol of national pride, the symbol of national identity, as a tool to unite people from a variety of socio-cultural backgrounds and used as a relationship between regions and intercultural [6]. Regional language is a language spoken in a particular region in Indonesia.

The word technology comes from the Greek language techne which means 'skill' and logia which means 'knowledge'. In short, the word technology refers to objects that are used for ease of human activity, such as machines, tools, or hardware. While the word sustainability is ongoing continuously or continuously. It is about sustainable technology in the sea fisheries Cilacap Regency. The modernization of fisheries through the application of inexpensive and precise technologies is essential to support national economic growth and increase productivity of fishermen.

Nowadays, the management of fisheries sector cannot be done effectively because there are many obstacles with lack of technological adoption, so it is needed technology improvement strategy. Fishermen have difficulty in adopting technology as most fishermen do not have access to the technology and in the use of fish fleet. The modernization of fisheries through the application of inexpensive and precise technologies is required to support the national economic growth and increase the productivity of fishing fishermen. Technology also plays a role in encouraging the development of the fishery industry so that it can increase the value added fisheries and increase the export of fishery products.

Fisheries according to Law No. 42 of 2009 is all activities related to the management and utilization of fish resources and the environment starting from preproduction, production, processing to marketing carried out in a fisheries business system. Business to face strict competition in order to realize the objectives of the company [7]. One type of fisheries is marine fisheries. The sea is a water space on earth that connects land to land and other natural forms, which is a geographical and ecological unit along with all related elements and whose boundaries and systems are determined 
by laws and regulations and international law (Law Number 32 the Year 2014). Therefore, marine fisheries are an activity related to the management and utilization of fish in the sea. Marine fisheries are a major contributor to healthy seafood. Many developing countries consider fish as a source of animal protein and a source of micronutrients for malnourished people [8]. However, the growing popularity of fish in economically developed or fast-developing countries creates demand that cannot be met by fish stocks in their waters (e.g. EU, US, China, and Japan).

The marine fisheries sector in Indonesia is a major commodity and contributes income for the people as fishermen and to the state [9]. Fisheries is an economic activity in the field of catching or cultivating fish or other aquatic animals or aquatic plants. Fishery's potential is divided into land and sea. The inland fisheries business is generally carried out by the people of Cilacap by maintaining carp, tilapia, and catfish. While marine fisheries business is generally carried out by coastal communities. At first, it still uses traditional fishing gear, and then over time, it uses modern equipment so that the catches obtained are better than before. To expedite fishing, several fish auction sites have been built as places to market the catches of Cilacap fishermen. Fishermen are people who actively carry out work activities in fishing operations or other aquatic animals and are not people who only do work such as making nets, transporting fishing equipment into boats or ships, but are engineers and cooks who work on fishing vessels included as fishermen, even though they did not directly catch them. This means that there is an ecological human relationship with the environment to fulfill daily life [10]. Where the environment for fishermen is the beach, because people work as fishermen residing around the beach.

In the world of fisheries needed a place to dock, namely the port. Fisheries port has an important role in marine fisheries because it is the center of the economy from fish landing to being marketed at the port. The port is one of the places consisting of land and waters around it with certain restrictions as a place of government activities and economic activities that are used by ships to dock, dock, get on and off passengers or unloading goods which are equipped with shipping safety facilities and supporting port activities as well as a place of transportation [11]. One type of port is a fishing port. Based on the Law of the Republic of Indonesia Number 45 of 2009, a fishing port is a place that consists of land and waters around it with certain limits as a place of government activities and fisheries business system activities that are used as fishing vessels resting, anchored, and or loading and unloading fish equipped with shipping safety facilities and fishery support activities. The role of fishing ports in marine fisheries is important to provide services to ships entering and leaving ports and landed catches [12]. Seen from international glasses, the seaport of the Seine axis (Le Havre, Rouen, and Paris) is the main entrance and exit gate for French international trade [13]. Meanwhile, according to Mihanovic et al. stated that the Port Infrastructure in the City of New Zealand consists of 6 industrial ports, 10 tourism ports 65 open ports for public transportation (39 local, 20 cities and six international), 49 sports - recreation, eight docks, four shipyards [14].

One of the ports in Java is located in Cilacap Regency. The Cilacap Ocean Fishery Port is the only oceanic fishing port located on the South Coast of Java and directly facing the Indonesian Ocean (WPP 573) which is known to have abundant potential fish resources. Geographically, the Cilacap Ocean Fisheries Port is located in Tegalkamulyan Village,
South Cilacap District, Cilacap Regency, Central Java Province, and positions 09 "01" 18.4 "East and 07" 43 '31.2 "LS.

The view of the development of the Cilacap Fishery Port was begun in the 1980s by the Directorate General of Fisheries by developing the PPP Sentolokawat. However, the plan encountered obstacles because its location was close to the docks and traffic of Pertamina tankers. Based on the results of the coordination meeting on August 14, 1989, it was decided that the construction of the Cilacap Fisheries Port was immediately carried out and Bappenas was appointed as the coordinator of the implementation team and Pertamina as the funder. Cilacap Fishery Port Development, following SK Coordinating Minister for the Economy and Wasbang Number Kep.09 / M. EKUIN / 1990 dated March 24, 1990, consists of 11 related agencies or Departments. Construction of the Cilacap Fisheries Port began in 1991/1992 and was completed in 1994. The operational trials were carried out on May 20, 1994, until May 24, 1995. On November 18, 1996, the Cilacap Ocean Fisheries Port was inaugurated by the President of the Republic of Indonesia. Initially, the status of the Cilacap Fishery Port was determined as a Fishery Port type B (Nusantara) following the approval of the Minister of State Apparatus Utilization on 16 August 1995. In subsequent developments, it increased to the Cilacap Ocean Fishery Port according to the approval of the Minister of Administrative Reform No 86 / M / PAN / 4 / 2001 April 4, 2001.

Sea fish is a species that spends at least a part of its life cycle at sea. Based on research Eschmeyer et al. states that marine fish occur into several groups, namely commercial groups with large species, commercial groups with small to medium species, and groups that have no commercial value and or with small species or species that are difficult to be caught [15]. Fish in various types of marine waters according to the fishing gear used. Based on research conducted by Zhu et al. species captured on longline observer trips in the middle-eastern part of the Pacific Ocean are tuna (bigeye tuna, yellowfin tuna, albacore, skipjack), billfish (swordfish, blue marlin), shark (blue shark, bigeye thresher, velvet dogfish, crocodile shark), others (pelagic stingray, longnose lancefish, big scale pomfret, sickle pomfret, escolar, black gemfish, wahoo) [16]. Reeves et al. state that efforts have been made both within the United Nations Agricultural Fisheries Organization (FAO) and IWC regarding fishing equipment in the form of gill nets consisting of gill nets (anchored), fixed gill nets, drift gills, triple-layer nets, and various other gills and nets [17]. Wada et al. stated that sea fish caught on the coast of Fukushima Prefecture in June 2016 used a sled net with a width of 3 meters, height 0.8 meters, net length of 9.0 meters with a tip of $5 \mathrm{~mm}$ which is operated by the Oshoro-maru training ship from Hokkaido University [18].

Varkey et al. state that fish species are divided proportionally into 57 functional groups of which 30 represent unique species and there are 1203 fish species represented in the RA model [19]. Fish has many benefits for the human body. Kupeli et al. stated that fish is one of the most important foods for health because it has high protein quality and nutritional value [20]. Fish is also highly recommended for babies, the elderly, heart patients, brain hemorrhage patients, and digestion. Therefore, fish have high mineral content and low energy levels. One type of fish is sea fish. Sea fish has been known as the most popular food source so that during the last five years from 2010-2014 capture fisheries production from sea waters tends to increase [21]. 
Fishing is needed by ships to reach the sea to be sailed. Various types of ships. The Government of Indonesia through the Ministry of Maritime Affairs and Fisheries and the Ministry of Transportation are actively conducting data collection of ships to determine the capacity of capture fisheries businesses operating in Indonesia to control fishing vessels operating in Indonesia [22]. The Philippines fishermen who use ships over $3 \mathrm{GT}$ is classified as commercial fishermen [23]. Hong Kong and Singapore differentiate based on inshore and offshore fisheries. Thailand differentiates based on ship weight, type of fishing gear used, and capture area.

The purpose of this study is to determine the role of marine fisheries in the Cilacap Ocean Fishery Port which includes types of fishing gear at sea, fish classification, processing of fish products, the number of fishermen, and the number of ships in the waters of Cilacap.

At the last five years, the production of marine capture that fluctuated by $11.226,58$ MT in 2013 than decreased 5.737,65 MT in 2014, and then increased in 2015 has to $13.317,71 \mathrm{MT}$, and then decrease in 2016 has to 7.966,55, while in 2017 increased again to $11.840,41 \mathrm{MT}$. However, on average an increase with increasing average $22.92 \%$ per year during 2013 $-2017$.

In periods $2013-2017$ the production of fish by fishing gears generally increased $22.91 \%$ per year. Meanwhile the production of demersal Danish seine increased $119.58 \%$, longline increased by $107.09 \%$, pelagic Danish seine increased $73.31 \%$, trammel net increased $45.06 \%$, drift longline other than tuna long line increased $38.68 \%$, bottom gill net increased $35.47 \%$, set gill nets increased $19.80 \%$, drift gillnet increased $17.83 \%$, for production portable trap are decrease $29.04 \%$, bouke ami decrease $25 \%$, monofilament drift gill net decrease $24.52 \%$, purse seine decrease $15.93 \%$ and bottom longline also decrease $5.68 \%$.

The export volume during 2013 - 2017 increased annually with an average $16.14 \%$ that were fresh fish and frozen fish, the highest increasing was 7.824,06 MT in 2017. The canned tuna production export periods 2013 - 2017, had increasing that is $1.695,56 \mathrm{MT}$ in 2013 to $1.973,75 \mathrm{MT}$ in 2017.

During 2013 - 2017, the production of marine capture fisheries by type of disposition increased annually with an average $22.92 \%$ per year, for frozen product increased annually with an average $31.70 \%$ per year. The increasing also occurs in marketing fresh product, preserving product, canning and live product that increased annually per year with an average $22.32 \%, 75.62 \%, 31.43 \%$ and $44.50 \%$.

\section{METHODS}

This research is a type of qualitative research. Bogdan and Taylor define qualitative research as research that generates descriptive data in the form of written or oral words of persons or behaviors that can be observed [24]. Research methods of case studies with aspects studied in the form of marine capture equipment, types of production processing and processed fishery products, number of fishermen, and the number of vessels based on vessel size and capture equipment. Therefore, qualitative research is a study that generates descriptive data and seeks to explore the meaning of a phenomenon [25]. Data can be written data in the form of documents or verbally from various sources.

\section{RESULT AND DISCUSSION}

Cilacap District Fisheries has a $5,200 \mathrm{~km}^{2}$ fishing leaflet with 33,000 fishermen and 4,538 fishing fleets consisting of 649 non-motorized boats, 1,139 outboard motors, 2,639 motorboats, and 2,639 long lines and 115 fruits and the number of fishing gear as many as 107,523 units. Cilacap Regency Marine Fisheries is also equipped with supporting facilities such 9as, Cilacap Ocean Fishery Port with a capacity of 250 vessels, 7 units of the jetty, 11 units of Provincial or District TPI, 2 fuel depots, 4 shipyards, ice plant capacity of 236 tons as many as 5 units, and 75 units of the cold storage capacity of 3 units.

Fisheries is a human activity related to the management and utilization of Fisheries Resources. The activity was carried out by fishermen using transportation consisting of fishing vessels and using fishing gear to get fish. After the fishermen get the fish then the fish is processed into certain products.

The marine and fisheries sector is a very important sector for Indonesia. This is inseparable from the position and strategic potential of Indonesia, known as an archipelago with an area reaching 3 times the land area. Marine and fisheries development as an integral part of national development, in Indonesia's independent, advanced and strong development, is guided by three pillars that support the development of the marine and fisheries sector, namely sovereignty, sustainability and prosperity.

Efforts to Manage Fish Resources Optimally, Manage and Manage Budgets with Expenditures for People's Prosperity, Prioritizing Expenditures for Fish Enrichment and Fish Raising, Fulfillment of Community Nutrition Needs, Raising Work Needs, and Increasing Expenditures to generate state foreign exchange. Based on this, in order to provide maximum benefits to the people and state of Indonesia and ensure the sustainability of the agricultural business itself, there has been a development and national fisheries activities directed at implementing sustainable fisheries principles.

Based on statistics from the Cilacap Ocean Fisheries Port there are 7 types or groups of fishing gear at sea, namely, trawl consisting of payang and dogol; gill nets consisting of drift gills, sirang, fixed / bottom gills, three layers, and monofilament gills; the trap consists of traps; fishing rods consisting of longline tuna, fixed base and stretch fishing line; purse seines include wrinkled 7 ring nets; squid fishing line; and lift nets which include bouke ami. The following Table 1 classifies the fishing equipment in the sea.

Table 1. Classification of Sea Fishing Equipment

\begin{tabular}{|c|c|c|}
\hline No. & Group & Category \\
\hline \multirow[t]{2}{*}{1} & Seine net & Pelagic danish seine \\
\hline & & Demersal danish seine \\
\hline \multirow[t]{5}{*}{2} & Gill Net & Drift gill net \\
\hline & & Shrimp entangling gill net \\
\hline & & Bottom set gill net \\
\hline & & Trammel net \\
\hline & & Monofilament drift gill net \\
\hline \multirow[t]{3}{*}{3} & Trap & Portable trap \\
\hline & Hook and liner & Tuna long line \\
\hline & & $\begin{array}{c}\text { Set bottom long line } \\
\text { Handlines }\end{array}$ \\
\hline 4 & Pukat cincin & Purse seine \\
\hline 5 & Pancing cumi & Squid Jigging \\
\hline 6 & Lift net & Stick held dift net \\
\hline
\end{tabular}


First, according to Ardidja [26], trawl (seine net) is a type of fishing gear in the form of a net that is very long with relatively small depth, with or without pockets in the middle, either operated from pantai (trawl beach) or from a ship (trawl tug) to confine a certain group of fish or water area. This tool is equipped with a pair of ropes (long) one end of the rope (the first picture) is fastened (for trawl trawling) or anchored (for trawl tug ship). The trawl used by Clacap fishermen consists of payang and dogol; Second, the gill net (gill net) is a fishing tool in the form of a rectangular shaped net with the same or uniform mesh size in all parts of the net. The gill nets used by Cilacap fishermen consist of drifting gills, aring sirang, fixed / basic gill nets, three-layer nets, and monofilament gill nets; Third, a trap is a tool to catch something and is usually given a bait. One of the fishing gears in the form of traps used by fishermen in Cilacap is Bubu. Bubu is a type of trap that has one or the entrance and can be easily lifted (either lifted by or without a boat or boat) to the fishing area. Installation of this tool near the surface of the water for a certain period. This tool has also required the installation of bait to attract the attention of fish to get into the trap tool; Fourth, fishing is a type of fishing gear consisting mainly of ropes and hooks. Sea fishing gear in the form of fishing line used by Cilacap fishermen consists of tuna longlines, fixed bottom longlines, and stretch fishing lines. Longline itself is a fishing gear consisting of a series of main ropes and on the main rope in a particular net, several branch ropes are shorter and smaller in diameter. At the end of the rope, a hook is attached to a fishing line.

Fifth, trawl ring is a fishing tool shaped almost quadrilateral to trapezoid formed from some combined webbing sheets that are attached to a buoy rope and ballast rope [26]. This tool is also equipped with a wrinkle strap and many rings. This tool is a very wide net so that it can confine a group of fish. The bottom of the net is attached by a wrinkled rope that can be pulled to cover the bottom of the net as well as a part of the net until some of the nets remains as a fish container to be lifted to the ship. The fishing gear in the sea in the form of trawl ring used by Cilacap fishermen is a wrinkle-lined ring net.

Sixth, squid fishing line is a type of fishing gear that has a special shape so that it is related to other forms of fishing. This fishing rod is shaped like a circular claw and terraced. The top and bottom are given holes or eyes that are useful for fastening fishing lines. Finally, lift nets are a type of quadrilateral fishing gear made of webbing [26]. However, sometimes the cone is mounted on a rigid frame made of iron, stone, bamboo, and rope. This tool is immersed in water even to the bottom of the water which is then raised to the surface to trap the fish that swim on it. Fish species in the sea are classified into 6 groups consisting of large pelagic fish resource groups, small pelagic fish, demersal fish, sharks or cones, hard-skinned and softskinned animals, as well as soft animals and other aquatic animals. The following table details the classification of fish species in the sea.

The industrial structure illustrates how the industry is organized. Industrial structure in the sea fishing port of Cilacap, the first will be carried out the registration of vessels in and out of the dock and withdrawal of retribution fee. Secondly, the ship is given logistics and supplies in the form of fuel, water, and ice. Thirdly, loading and unloading of all $\mathrm{ABK}$, weighing and retribution and packing by merchants. Fourth, there is a place for marketing and distribution of fish. The Following Figure 1 details the industrial structure of the ocean fishing port Cilacap. The treatment and production of processed fishery products at the Cilacap ocean fishing port consists of 5 types, starting from the fresh market; traditionally consisting of drying and salting, boiling, fermentation, fumigation, or burning and others; freezing; canning; and fish grinding. The following Table 2 details the classification of treatment and processed fisheries products.

Fishermen are people who work fishing in the sea. Working activities interpreted to make a living to earn money [27]. Fishermen in Cilacap Regency especially in the Cilacap Sea Fisheries totaled 5,626 people consisting of 2,422 tuna longai fishermen, 12 fishing rod fishermen, 1,344 gill drift fishermen, 32 sirang net fishermen, 328 monofilament gill nets, 548 gill net fishermen 550 people, 144 payang fishermen, 152 arad fishermen, 180 trawlers, 20 net fishermen, 120 squid fishermen, $80 \mathrm{Bubu}$ fishermen, 80 fishermen, and fishermen. Based on these data it can be concluded that the largest number of fishermen is longline tuna fishermen and the smallest is fisherman fishing rods. The following Table 3 detail the number of fishermen by sea fishing vessel category.

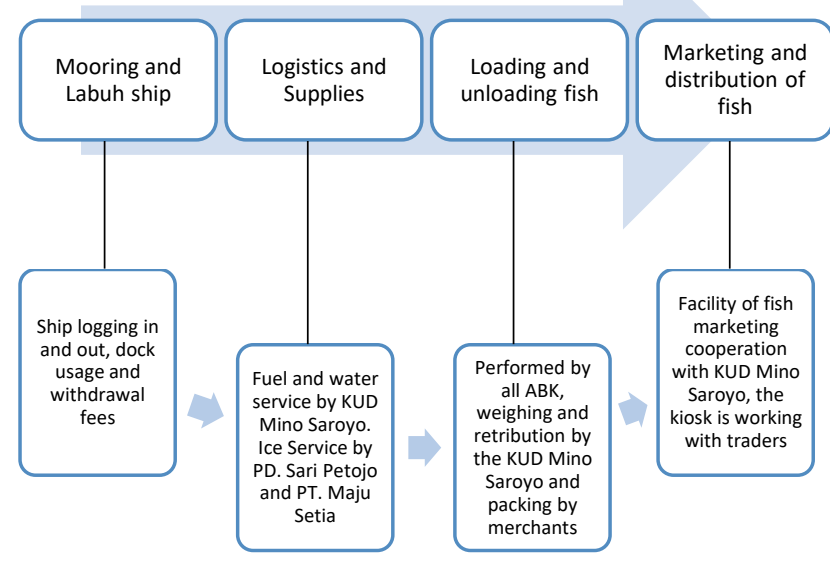

Figure 1. Industrial structure of the ocean fishing port Cilacap

Table 2. Classification of treatment and production of processed capture fisheries

\begin{tabular}{lll}
\hline No. & \multicolumn{1}{c}{ Type of Treatment } & \multicolumn{1}{c}{ Types of Processed Results } \\
\hline 1 & Marketed fresh & Fresh fish, whole fish or cut fish \\
& Traditionally processed & Dried fish, salted fish \\
& a. Dried or salted & Pindang fish \\
2 & b. Boiled down & Shrimp Paste \\
& c. Fermentation (made shrimp paste) & Smoked fish or grilled fish \\
& d. Fumigating or Burning $\quad$ Etc & Fish crackers, shrimp crackers, fish jerky \\
3 & e. Freezing & Frozen fish, whole frozen fish, or frozen cut fish \\
4 & Canning & Canned fish \\
5 & Fish grinding & Fishball, fish nugget, fish sausage \\
\hline
\end{tabular}


Table 3. Number of fishermen by sea fishing vessel category (Statistics of the Ocean Fishery Port of Cilacap)

\begin{tabular}{|c|c|c|c|c|c|c|c|c|c|c|c|c|c|c|c|c|c|}
\hline \multirow[b]{3}{*}{$\begin{array}{l}\text { D } \\
\vdots \\
0 \\
\vdots \\
0 \\
0 \\
\stackrel{0}{0} \\
0 \\
0 \\
0\end{array}$} & \multirow[b]{3}{*}{$\underset{\theta}{\nabla}$} & \multicolumn{16}{|c|}{ FISHERMEN FULL TIME } \\
\hline & & \multicolumn{3}{|c|}{ Long Line } & \multicolumn{5}{|c|}{ Gill Net } & \multicolumn{2}{|c|}{ Seine net } & \multirow[b]{2}{*}{ 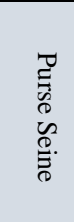 } & \multirow[b]{2}{*}{$\underset{\substack{Z \\
\infty}}{Z}$} & \multirow[b]{2}{*}{ 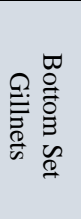 } & \multirow[b]{2}{*}{$\begin{array}{l}\overrightarrow{0} \\
\stackrel{\tilde{\tilde{\sigma}}}{\sigma} \\
\overrightarrow{0} \\
\overrightarrow{\tilde{z}}\end{array}$} & \multirow[b]{2}{*}{$\begin{array}{l}\text { Q. } \\
\stackrel{\Xi}{\Xi} .\end{array}$} & \multirow[b]{2}{*}{$\begin{array}{l}\overrightarrow{0} \\
\stackrel{0}{3} \\
\gtrless\end{array}$} \\
\hline & & 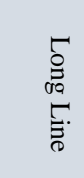 & 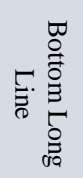 & 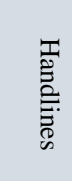 & $\frac{\substack{0 \\
0}}{\stackrel{0}{E}}$ & 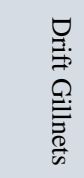 & 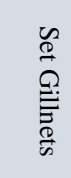 & 窇 & 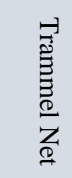 & 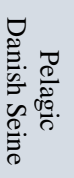 & 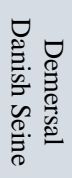 & & & & & & \\
\hline 1 & $\begin{array}{c}35 \\
6 \\
\end{array}$ & 350 & 2 & - & - & 396 & 32 & 484 & 440 & 72 & 144 & 60 & - & - & 80 & - & 2,050 \\
\hline 2 & 43 & 392 & - & - & - & 252 & - & 48 & 60 & 72 & 8 & 30 & - & 45 & - & 10 & 917 \\
\hline 3 & 32 & 798 & - & - & - & 348 & - & - & 30 & - & - & 30 & - & 45 & - & - & 1,251 \\
\hline 4 & 13 & 350 & - & - & - & 228 & - & 16 & 20 & - & - & - & - & - & - & - & 614 \\
\hline 5 & 3 & 84 & - & 12 & - & 48 & - & - & - & - & - & 30 & - & 30 & - & 10 & 214 \\
\hline 6 & 4 & 308 & - & - & - & 12 & - & - & - & - & - & - & 10 & - & - & - & 330 \\
\hline 7 & - & - & - & - & - & - & - & - & - & - & - & - & - & - & - & - & - \\
\hline 8 & 1 & 56 & - & - & - & 24 & - & - & - & - & - & 30 & 10 & - & - & - & 120 \\
\hline 9 & 1 & 84 & - & - & - & 36 & - & - & - & - & - & - & - & - & - & - & 120 \\
\hline$>10$ & - & - & - & - & - & - & - & - & - & - & - & - & - & - & - & - & - \\
\hline $\begin{array}{l}\text { TOTA } \\
\mathrm{L}\end{array}$ & $\begin{array}{c}45 \\
3 \\
\end{array}$ & 2,422 & 2 & 12 & - & 1,344 & 32 & 548 & 550 & 144 & 152 & 180 & 20 & 120 & 80 & 20 & 5,626 \\
\hline \multicolumn{2}{|c|}{$\begin{array}{c}\text { Percentage } \\
(\%)\end{array}$} & $\begin{array}{c}43.05 \\
\% \\
\end{array}$ & $\begin{array}{c}0.04 \\
\%\end{array}$ & $\begin{array}{c}0.21 \\
\%\end{array}$ & $\begin{array}{c}0.00 \\
\%\end{array}$ & $\begin{array}{c}23.89 \\
\% \\
\end{array}$ & $\begin{array}{c}0.57 \\
\%\end{array}$ & $\begin{array}{c}9.74 \\
\% \\
\end{array}$ & $\begin{array}{c}9.78 \\
\% \\
\end{array}$ & $\begin{array}{c}2.56 \\
\% \\
\end{array}$ & $\begin{array}{c}2.70 \\
\%\end{array}$ & $\begin{array}{c}3.20 \\
\%\end{array}$ & $\begin{array}{c}0.36 \\
\%\end{array}$ & $\begin{array}{c}2.13 \\
\%\end{array}$ & $\begin{array}{c}1.42 \\
\%\end{array}$ & $\begin{array}{c}0.36 \\
\%\end{array}$ & $\begin{array}{c}100.00 \\
\%\end{array}$ \\
\hline
\end{tabular}

Table 4. Number of sea fishing vessels by ship size (Cilacap Ocean Fisheries Port Statistics)

\begin{tabular}{|c|c|c|c|c|c|c|c|c|c|}
\hline & \multirow[b]{3}{*}{ DESCRIPTION } & \multicolumn{7}{|c|}{ SIZE OF FISHING BOAT } & \multirow[b]{3}{*}{ TOTAL } \\
\hline & & \multicolumn{6}{|c|}{ Inboard Engine } & \multirow{2}{*}{$\begin{array}{c}\text { Outboard } \\
\text { Engine }\end{array}$} & \\
\hline & & 5-10GT & $\begin{array}{c}11-20 \\
\text { GT }\end{array}$ & $\begin{array}{c}21-30 \\
\text { GT }\end{array}$ & $\begin{array}{c}\text { 31-50 } \\
\text { GT }\end{array}$ & $\begin{array}{l}\text { 51-200 } \\
\text { GT }\end{array}$ & $\begin{array}{c}\text { Sub } \\
\text { Total }\end{array}$ & & \\
\hline \multirow{3}{*}{ Long Line } & Tuna Long Line & - & 5 & 133 & 20 & 15 & 173 & - & 173 \\
\hline & Bottom Long Line & - & - & 1 & - & - & 1 & - & 1 \\
\hline & Handlines & - & - & 1 & - & - & $\mathbf{1}$ & 16 & 17 \\
\hline \multirow[t]{5}{*}{ Gillnets } & Bottom Set Gill nets & - & - & - & - & - & - & - & - \\
\hline & Drift Gill nets & 17 & 12 & 83 & - & - & 112 & - & 112 \\
\hline & Set Gill nets & - & - & - & - & - & - & 8 & 8 \\
\hline & Monofilament Drift Gill nets & - & - & - & - & - & - & 137 & 137 \\
\hline & Trammel net & - & - & - & - & - & - & 110 & 110 \\
\hline \multirow[t]{2}{*}{ Seine Net } & Pelagic Danish Seine & - & - & - & - & - & - & 12 & 12 \\
\hline & Demersal Danish Seine & - & - & - & - & - & - & 38 & 38 \\
\hline \multicolumn{2}{|r|}{ Purse Seine } & - & - & - & 1 & 5 & 6 & - & 6 \\
\hline \multicolumn{2}{|r|}{ Portable Trap } & - & - & - & - & - & - & 20 & 20 \\
\hline \multicolumn{2}{|r|}{ Squid Jigging } & - & - & - & 2 & 6 & 8 & - & 8 \\
\hline \multicolumn{2}{|r|}{ Cats Nets } & - & - & - & - & 2 & 2 & - & 2 \\
\hline \multirow{2}{*}{\multicolumn{2}{|c|}{$\begin{array}{c}\text { Carrier } \\
\text { TOTAL }\end{array}$}} & - & - & 1 & - & 1 & 2 & - & 2 \\
\hline & & 17 & 17 & 219 & 23 & 29 & 305 & 341 & 646 \\
\hline \multicolumn{2}{|c|}{ Persentase / Percentage (\%) } & $2.63 \%$ & $2.63 \%$ & $33.90 \%$ & $3.56 \%$ & $4.49 \%$ & $47.21 \%$ & $52.79 \%$ & $100.00 \%$ \\
\hline
\end{tabular}

Table 5. Number of sea fishing vessels according to fishing equipment (Statistics of Ocean Fisheries Port of Cilacap)

\begin{tabular}{|c|c|c|c|c|c|c|c|c|c|c|c|c|c|c|c|c|}
\hline \multirow[b]{3}{*}{$\begin{array}{l}\text { SIZE OF } \\
\text { BOAT }\end{array}$} & \multicolumn{16}{|c|}{ TYPE OF FISHING GEARS } \\
\hline & \multicolumn{3}{|c|}{ Long Line } & \multicolumn{5}{|c|}{ Gillnets } & \multicolumn{2}{|c|}{ Seine net } & \multirow[b]{2}{*}{ 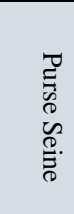 } & \multirow[b]{2}{*}{ 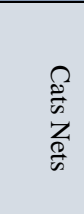 } & \multirow[b]{2}{*}{ 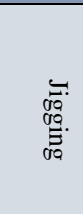 } & \multirow[b]{2}{*}{ 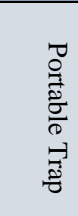 } & \multirow[b]{2}{*}{ 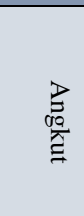 } & \multirow{2}{*}{$\begin{array}{l}\mathbf{T} \\
\mathbf{O} \\
\mathbf{T} \\
\mathbf{A} \\
\mathbf{L}\end{array}$} \\
\hline & $\begin{array}{c}5 \\
5 \\
90 \\
5 \\
5 \\
5\end{array}$ & : & : & 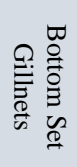 & 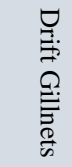 & 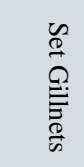 & $=\frac{3}{0}$ & 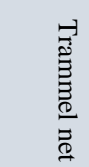 & 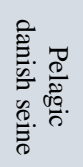 & 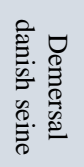 & & & & & & \\
\hline 5-10 GT & - & - & - & - & 17 & - & - & - & - & - & - & - & - & - & - & 17 \\
\hline 11-20 GT & 5 & - & - & - & 12 & - & - & - & - & - & - & - & - & - & - & 17 \\
\hline 21-30 GT & 133 & 1 & 1 & - & 83 & - & - & - & - & - & - & - & - & - & 1 & 219 \\
\hline 31-50 GT & 20 & - & - & - & - & - & - & - & - & - & 1 & - & 2 & - & - & 23 \\
\hline 51-200 GT & 15 & - & - & - & - & - & - & - & - & - & 5 & 2 & 6 & - & 1 & 29 \\
\hline $\begin{array}{l}\text { Outboard } \\
\text { Engine }\end{array}$ & - & - & 16 & - & - & 8 & 137 & 110 & 12 & 38 & - & - & - & 20 & - & 341 \\
\hline TOTAL & 173 & 1 & 17 & - & 112 & 8 & 137 & 110 & 12 & 38 & 6 & 2 & 8 & 20 & 2 & 646 \\
\hline $\begin{array}{l}\text { Percentage } \\
(\%)\end{array}$ & $\begin{array}{l}26.7 \\
8 \%\end{array}$ & $\begin{array}{l}0.15 \\
\%\end{array}$ & $\begin{array}{l}2.63 \\
\%\end{array}$ & $\begin{array}{l}\mathbf{0 . 0 0} \\
\%\end{array}$ & $\begin{array}{l}17 \\
\%\end{array}$ & $\begin{array}{l}1.24 \\
\%\end{array}$ & $\begin{array}{l}21.21 \\
\%\end{array}$ & $\begin{array}{l}17.03 \\
\%\end{array}$ & $\begin{array}{l}1.86 \\
\%\end{array}$ & $\begin{array}{l}5.88 \\
\%\end{array}$ & $\begin{array}{l}0.93 \\
\%\end{array}$ & $\begin{array}{l}0.31 \\
\%\end{array}$ & $\begin{array}{l}1.24 \\
\%\end{array}$ & $\begin{array}{l}3.10 \\
\%\end{array}$ & $\begin{array}{l}\mathbf{0 . 3 1} \\
\%\end{array}$ & $\begin{array}{l}100 \\
\%\end{array}$ \\
\hline
\end{tabular}

Based on Table 4 details on the number of sea fishing vessels by ship size in Ocean Fisheries Port of Cilacap. The fishing fleet with a base of 646 units, with a composition based on the number of types of fishing gear, is dominated by, 173 lines of longline, 137 units of monofilament gills, 112 units of drift gills, 110 units of three layers, 38 units of Arad, 17 units 
of fishing rods, 20 units of bubu, 12 units of payang, 8 units of sirang nets, 6 units of trawlers, 2 units of nets fell, 8 units of squid fishing, 2 units of transporting vessels and 1 unit of longline the unit.

Based on Table 5 details on the number of sea fishing vessels according to fishing equipment in Ocean Fisheries Port of Cilacap. The fleet is dominated by 341 outboard motorboats, 21-30 GT motorcycles, 219 units followed by 51 - 200 GT motorbikes, 29 units, then 31 - 50 GT motorbikes, 23 units, 23 motorbike boats. 11 - 20 GT for 17 units, motorboats measuring 5-10 for 17 units.

The abundant natural resources of the sea in Cilacap Regency can be processed and able to serve as a source of economy for coastal community Cilacap. Results of marine products in the Cilacap region according to the treatment period 2013-2017 consist of fresh fish products, pickling, canning, and living products. Where the dominant product results experienced an average increase per year is preservation. One of the results of the preservation of marine production is salty fish. Salted fish without preservatives with attractive packaging can be penetrated to foreign markets. In addition to having a very tinngi protein, salty fish also have a savory and delicious flavor. Moreover, see the development, the typical salted fish of Cilacap has been processed professionally that is the originality of flavor without mixed with preservatives. In addition, the pretty slick salted fish packaging also becomes one of its own freshwater values to attract consumer interest. This can be seen from the development of the salty fish market in Cilacap Regency that continues to expand and reach consumers from Java, Sumatera, Bali, Kalimantan, Sulawesi and Lombok. The Cilacap salted fish products have also penetrated to foreign markets such as Japan, Taiwan, Malaysia, Abudabi, Hongkong, Spain and Korea. Today, the market is still through a third party, namely the exporters who are in Jakarta and Surabaya.

In order to improve the results of fishing, many efforts made by fishermen as the main perpetrators of fishing activities in the sea, both carried out by large-scale fishermen and small scale. Some of these efforts have been concerned about the machining of vessels, fishing tools and fishing aids. In the field of fishing equipment in the development has been done many modifications, so it becomes not in accordance with the standard of existing rules. If viewed from the way of operation and construction there are several fishing tools that are environmentally friendly and there is also a capture device that is not environmentally friendly so it is forbidden to use/operate. Trammel Net Capture tool is an environmentally friendly capture tool. Among the fishermen Kaliwungu Trammel net is often called the net of Sirang where the catch is a belanak fish.

In the fiscal year 2019 this fisheries office of Cilacap Regency through the field of fishery capture organized a Trammel Net fishing equipment manufacturing training. Trammel Net Fishing Equipment Making training is held in Kaliwungu Village, Kedungreja Sub-district, Cilacap Regency. The purpose and objectives carried out in Trammel Net fishing equipment manufacture training is to introduce to fishermen, equip the knowledge and skills to the fishermen about the Trammel Net fishing equipment and its manufacturing practices. It is hoped that after attending the training of fishermen/trainees are able to make their own trammel net fishing equipment thus reducing the cost of operating expenses because it has been equipped to be able to create and repair its own nets.

Therefore, there was a large school of fishermen (SLN) held by the meteorological station of Klimatology and Geophysical (BMKG). The large school of fishermen followed by 25 participants from fisheries and fishermen and in Cilacap Regency aims to increase understanding and skills in accessing the maritime weather information so as to create economic and safety improvements. Moreover, the activities of the fishing field school also aim to make the data and information of BMKG be used more optimally for the increase of fishermen's catches.

\section{CONCLUSION}

The ocean fishing port of Cilacap is the only sea fishing port located on the south coast of Java and facing directly with the Indonesian ocean that is known for its abundant potential fish resources. In order to provide maximum benefit for Indonesian society and State and ensure the sustainability of the fisheries business itself, the development and activities of national fisheries are immediately directed to apply the rules of sustainable fisheries. The modernization of fisheries through the application of cheap and precise technology is necessary to support economic growth and increase productivity of fishing tangkapa. In order to increase the results of fishing, many fishermen's efforts are concerned about the machining of vessels, fishing equipment and fishing aids. In the field of fishing equipment in the development has been done many modifications, so it becomes not in accordance with the standard of existing rules. If viewed from the way of operation and construction there are several fishing tools that are environmentally friendly and there is also a capture device that is not environmentally friendly so it is forbidden to use/operate. Trammel Net Capture tool is an environmentally friendly capture tool.

\section{REFERENCES}

[1] Siombo, M.R. (2010). Hukum Perikanan Nasional dan Internasional. Jakarta: PT Gramedia Pustaka Utama.

[2] Manik, H.M. (2014). Teknologi akustik bawah air: solusi data perikanan laut Indonesia. Risalah Kebijakan Pertanian dan Lingkungan, 1(3): 181-186.

[3] Depellegrin, D., Menegon, S., Gusatu, L., Roy, S., Misiune, L. (2020). Assessing marine ecosystem services richness and exposure to anthropogenic threats in small sea areas: A case study for the Lithuanian sea space. Ecological Indicators, 108: 105730. https://doi.org/10.1016/j.ecolind.2019.105730

[4] Saddhono, K., Rohmadi, M. (2014). A sociolinguistics study on the use of the Javanese language in the learning process in primary schools in Surakarta, Central Java, Indonesia. International Education Studies, 7(6): 25-30. http://dx.doi.org/10.5539/ies.v7n6p25

[5] Saddhono, K. (2018). Cultural and social change of foreign students in Indonesia: The influence of Javanese Culture in Teaching Indonesian to Speakers of Other Languages (TISOL). IOP Conference: Earth and Environmental Science, 126: 012091. https://doi.org/10.1088/1755-1315/126/1/012091

[6] Saddhono, K., Sulaksono, D. (2018). Indoglish as adaptation of english to Indonesian: Change of society in big cities of Indonesia. IOP Conference Series: Earth and Environmental Science, 126: 012092. 
https://doi.org/10.1088/1775-1315/126/1/012092

[7] Saddhono, K., Chin, J., Toding, A., Qadri, M.N., Wekke, I.S. (2019). Competitive intelligence: Systematic collection and analysis of information. Journal of Critical Reviews, $6(5)$ : 155-159. https://doi.org/10.22159/jcr.06.05.27

[8] Pauly, D., Zeller, D. (2016). Catch reconstructions reveal that global marine fisheries catches are higher than reported and declining. Article Nature Communications, 7: 1-9. https://doi.org/10.1038/ncomms 10244

[9] Setyawan, B.W., Saddhono, K. (2017). Eret ceremony as representation of mutual cooperation spirit among coastal society. Journal of Computational and Theoretical Nanoscience, 23(10): 9991-9992. https://doi.org/10.1166/asl.2017.10363

[10] Sulaksono, D., Saddhono, K. (2018). Strengthening character of environment preservation using Wayang story Lakon Dewa Ruci: An ecological literature analysis. International Journal of Education, Language, and Literature, 1(1): 28-34.

[11] Sasono, H.B. (2012). Manajemen Pelabuhan dan Realisasi Ekspor Impor. Yogyakarta: ANDI.

[12] Lubis, E. (2011). Kajian peran strategis pelabuhan perikanan terhadap pengembangan perikanan laut. Akuatik Jurnal Sumberdaya Perairan, 5(2): 1-7.

[13] Serry, A. (2018). The seaports of the seine axis facing contemporary maritime industry mutation. Transactions on Maritime Science, 7(2): 199-127. https://doi.org/10.7225/toms.v07.n02.001

[14] Mihanovic, V., Peronja, I., Vukic, L. (2019). Port area of the split port authority in the function of economic development: Concessionaires attitudes. Trans. marit. Sci., 02 :

213-229. https://doi.org/10.7225/toms.v08.n02.006

[15] Eschmeyer, W.N., Fricke, R., Fong, J.D., Polack, D.A. (2010). Marine fish diversity: history of knowledge and discovery (Pisces). Zootaxa, 2525: 19-50.

[16] Zhu, J.F., Xu, L.X., Dai, X.J., Chen, X.J., Chen, Y. (2012). Comparative analysis of depth distribution for seventeen large pelagic fish species captured in a longline fishery in the central-eastern Pacific Ocean. Scientia Marina, 76(1): 149-157. https://doi.org/10.3989/scimar.03379.16C

[17] Reeves, R.R., McClellan, K., Werner, T.B. (2013). Marine mammal by catch in gillner and other entangling net fisheries 1990 to 2011. Endangered Species Research,
20: 71-97. https://doi.org/10.3354/esr00481

[18] Wada, T., Konoplev, A., Wakiyama, Y., Watanabe, K., Furuta, Y., Morishita, D., Kawata, G., Nanba, K. (2019). Strong contrast of cesium radioactivity between marine and freshwater fish in Fukusima. Journal of Environmental Radioactivity, 204: 132-142. https://doi.org/10.1016/j.jenvrad.2019.04.006

[19] Varkey, D., Ainsworth, C.H., Pitcher, T.J. (2012). Modelling reef fish population responses to fisheries restrictions in marine protected areas in the coral triangle. Hindawi Journal of Marine Biology, 2012: 1-18. https://doi.org/10.1155/2012/721483

[20] Kupeli, T., Altundag, H., Imamoglu, M. (2014). Assessment of trace element levels in muscle tissues of fish species from a river, stream, lake, and sea in Sakarta, Turkey. Hindawi The Scientific World Journal. https://doi.org/10.1155/2014/496107

[21] Talumepa, C.A.N., Suptijah, P., Wullur, S., dan Rumengan, I.F.M. (2016). Kandungan kimia dari sisik beberapa jenis ikan laut. Jurnal LPPM Bidang Sains dan Teknologi, 3(1): 27-33.

[22] Sunardi, B.A., Sulkhani, E. (2019). Gross tonnage calculation on fishing vessels based on Indonesian regulation and a computer aided modeling (case study of fishing vessels in Muncar and Prigi). Marine Fisheries, 10(2): 141-152.

[23] Tawari, R.H.S., Simbolon, D., Purbayanto, A., dan Taurusman, A.A. (2014). Fishing fleet optimization analysis of small scale yellowfin tuna in west Seram regency. Marine Fisheries, 5(2): 129-137.

[24] Djamal, M. (2015). Paradigma Penelitian Kualitatif. Yogyakarta: Pustaka Pelajar.

[25] Saddhono, K. (2017). Language of coastal communities in the northern coast of central java: sociolinguistic studies in cultural integration maritime-agrarian perspective. Advanced Science Letters, 23(10): 1005410056.

[26] Ardidja, S. (2007). Alat Penangkap Ikan. Sekolah Tinggi Perikanan Jurusan Teknologi Penangkapan Ikan Jakarta.

[27] Saddhono, K., Kurniawan, A. (2017). Islamic religious value in traditional ceremony of Begalan Banyumasan as educational character for student at senior high schools in central java. UMRAN International Journal of Islamic and Civilizational Studies, 4(1): 71-77. https://doi.org/10.11113/umran2017.4n1-1.206 